\title{
Gene flow in Prunus species in the context of novel trait risk assessment
}

\author{
S. Zahra H. CICl${ }^{*}$ and Rene C. VAN ACKER ${ }^{1}$ \\ Department of Plant Agriculture, University of Guelph, Guelph, ON, N1G2W1, Canada
}

Prunus species are important commercial fruit (plums, apricot, peach and cherries), nut (almond) and ornamental trees cultivated broadly worldwide. This review compiles information from available literature on Prunus species in regard to gene flow and hybridization within this complex of species. The review serves as a resource for environmental risk assessment related to pollen mediated gene flow and the release of transgenic Prunus. It reveals that Prunus species, especially plums and cherries show high potential for transgene flow. A range of characteristics including; genetic diversity, genetic bridging capacity, inter- and intra-specific genetic compatibility, self sterility (in most species), high frequency of open pollination, insect assisted pollination, perennial nature, complex phenotypic architecture (canopy height, heterogeneous crown, number of flowers produced in an individual plant), tendency to escape from cultivation, and the existence of ornamental and road side Prunus species suggest that there is a tremendous and complicated ability for pollen mediated gene movement among Prunus species. Ploidy differences among Prunus species do not necessarily provide genetic segregation. The characteristics of Prunus species highlight the complexity of maintaining coexistence between GM and non-GM Prunus if there were commercial production of GM Prunus species. The results of this review suggest that the commercialization of one GM Prunus species can create coexistence issues for commercial non-GM Prunus production. Despite advances in molecular markers and genetic analysis in agroecology, there remains limited information on the ecological diversity, metapopulation nature, population dynamics, and direct measures of gene flow among different subgenera represented in the Prunus genus. Robust environmental impact, biosafety and coexistence assessments for GM Prunus species will require better understanding of the mechanisms of gene flow and hybridization among species within the Prunus species complex.

Keywords: Prunus / coexistence / pollen mediated gene flow / ferality / GM plum / biosafety

\section{INTRODUCTION}

Prunus species have been grown throughout the world for centuries. This genus contains ornamental plants (Cherry plum (Prunus cerasifera Ehrh.), a wide range of ornamental cherries), fully fertile hybrids (sour cherry $(P$. cerasus L.)), invasive plants (black cherry (P. serotina Ehrh.) in Europe), stone fruits (plums: P. domestica L., $P$. insititia L., $P$. cerasifera Ehrh.; apricot ( $P$. armenica L.); peach (P. persica (L.) Batsch.); cherries: $P$. avium L., $P$. cerasus L.) and one of the most common tree nut species (almond (P. communis Archang.)). The worldwide harvested area of Prunus fruit trees in 2009 was approximately 6.4 million hectares. Among commercial Prunus species, plums are the most commonly cultivated with a global total cultivated area of near 2.5 million hectares. Total global farm-gate value for Prunus production in 2009 was approximately $\$ 41$ billion (US dollars)

* Corresponding author: vanacker@uoguelph.ca and global export trade value was $\$ 6.6$ billion (US dollars) (FAOSTAT, 2010).

Like other crop plants, Prunus species have long been targeted for improvement through breeding. With advances in genetics, the ability to utilize germplasm from related Prunus species has increased the options for improving commercial Prunus trees. In traditional breeding, multiple backcrosses for successful gene introgression and a longer seed to seed cycle for trees limits the speed of breeding efforts. Genetic modification (GM, or genetic engineering - GE), on the other hand, speeds up breeding efforts, is not limited by incompatibility barriers and allows gene transfer between divergent taxon (Singh and Sansavini, 1998).

Although GM is compelling because of the opportunity to facilitate the introduction of many traits in breeding efforts, there are concerns held by the public and scientists regarding the safety of GM or GM facilitated traits. In recent years there have been an increasing number of reports on the potential risks of GM plants 
to the environment, often facilitated by intra- and interspecific transgene movement (Ho et al., 2007; Marvier and Van Acker, 2005). Plant to plant gene movement is facilitated by wind, pollinators, animals (especially birds), volunteer and feral populations, human transport of seeds and human error in seed handling. Once transgenes escape into the environment they are difficult, if not impossible, to retract. This can be seen in cases of invasive plants or the asymmetric gene flow that can lead to genetic assimilation and consequently increase the risk of wild taxa extinction (Marvier and Van Acker, 2005; Rhymer and Simberloff, 1996). There are also some concerns that GM techniques introduce undesirable genes along with useful genes into plants. From 50 selectable marker genes available for GM research three have been very widely used (Miki and McHugh, 2004). These three genes encode for resistance to the herbicide phosphinothricin and to the antibiotics hygromycin and kanamycin. In the case of herbicide resistance markers, there is a fear that the markers will contribute to the creation of invasive herbicide resistant plants. In the case of antibiotic resistance markers, there is concern that their presence in GM plants could lead to an increase in antibiotic-resistant bacterial strains and horizontal gene movement (for a review see Miki and McHugh, 2004). For example, horizontal gene movement has been recognized as a major force in the generation of pathogenic microbes (de Vries et al., 2004). Concerns over the safety of GM crops have lead to differential rates of deregulation and adoption of GM crops around the world. In turn this has lead to a need in some cases to segregate GM and non-GM crops and to manage their coexistence (Bagavathiannan et al., 2010).

To-date, papaya (Carica papaya L.) is the only transgenic tree fruit commercially grown (Ferreira et al., 2002). A plum variety ( $P$. domestica L.) resistant to Plum pox virus (PPV) called "C5 plum or Honey Sweet" (Scorza et al., 1994) has been deregulated in the United States (US) and may be the next commercially produced GM tree fruit (Scorza et al., 2007). PPV is a potyvirus that affects all stone fruit species and causes a disease called Sharka (or plum pox) and was first reported in Bulgaria (Atanassov, 1932). Natural resistance to this virus has been found in the wild peach relative $P$. davidiana (Carr.) Franch. (Pascal et al., 1998) and in almond (Rubio et al., 2003). The viral resistance in GM plum comes via posttranscriptional gene silencing and it contains the PPV coat protein gene (Scorza et al., 2001). One safety concern with the use of viral transgenes is the potential for synergism and transcomplementation which is mediated in plants by viral proteins including inhibitors of gene silencing, replicates and coat proteins (Latham and Wilson, 2008). Synergism occurs during simultaneous infection by two distinct viruses when infection of one or both viruses is enhanced. Viral synergisms are mostly proteinmediated and synergism can be mimicked in GM plants expressing single viral proteins (Latham and Wilson, 2008). In transcomplementation, an expressed viral protein from transgene enhances infection by an invading dependent virus (see the examples in Latham and Wilson, 2008).

Proponents of the PPV resistant GM plum note that it will help farmers to use fewer insecticides to control the aphids which act as PPV vectors. Opponents of this GM plum suggest that the coexistence of GM and non-GM tree fruits will be impossible and the market for non-GM tree fruits will be threatened. In the case of coexistence, scenarios for transgene movement from crop to crop has been well documented for many field crops (Van Acker et al., 2007) but this is not the case for tree fruits and the complexity of coexistence for Prunus species is compounded by the possibilities of genetic compatibilities among so many species within the taxon, the frequency of self-incompatibility, insect vectored gene flow and the long lived perennial nature of these tree fruit species. Insect pollinated species show a wider range of outcrossing rates (Goodwillie et al., 2005) versus wind pollinated species (Culley et al., 2002) and compared to annuals, perennials tend to have higher levels of outcrossing (Petit and Hampe, 2006). In addition, tree species are heterogeneous within individual crowns, and differences in outcrossing rates between upper and lower parts of a given tree are possible (Patterson et al., 2004).

Very few studies have been done of unassisted gene flow between wild and domesticated Prunus species. Besides compatibility, information concerning blooming dates and length of flowering periods in both wild and cultivated trees is relevant to considerations of transgene movement and containment. Asynchronous flowering timing can be an important prezygotic barrier to hybridization but it can be highly variable among sites and years. Flowering onset dates in a single Prunus species variety can vary by as much as 40 days (Szabo et al., 2003a, 2003b). Changes in ecological conditions may result in flowering overlap and increased gene flow between cultivated and wild species (Ellstrand and Schierenbeck, 2000). For example, despite traditional reports that gene pools of domestic apple (Malus domestica Borkh., $2 x$ ) and native apples (M. coronaria (L.) Miller., $4 x$ ) remain distinct (Dickson et al., 1991), a recent study in Ontario, Canada demonstrates the potential for gene flow from domestic feral apples to a native population (Kron and Husband, 2009). In this study individual feral and native trees were intermixed within a single site and from unassisted interspecific crosses $27.5 \%$ of seeds collected from tetraploid adult apple trees (native) were triploid or pentaploid hybrids. More seeds per fruit were produced in between-species crosses than within-species crosses 
(4.67 vs. 3.88). The number of viable seeds and their relative fitnesses was not reported. However, in another study on apple, Reim et al. (2006) found successful outcrossing at distances of up to $104 \mathrm{~m}$ with the resultant hybrid seed showing a germination rate of $80 \%$.

With the first GM Prunus deregulated in the USA there is a need to consider the possibility of transgene movement among Prunus species. It is important to review what is known in this regard so that we can determine where there are substantive gaps in knowledge that need to be addressed in order to facilitate risk assessments of GM Prunus species and the practicality of coexistence between GM and non-GM Prunus species.

\section{HYBRIDIZATION AND COMPATIBILITY AMONG PRUNUS SPECIES}

Hybridization is an evolutionary force that can reshape the genetic composition of a population and generate novel genotypes (Darwin, 1883). Hybridization between genetically distinct taxa has been suggested as one of the mechanisms facilitating an evolution to invasiveness in both native and introduced plants (Bagavathiannan and Van Acker, 2008; Ellstrand and Schierenbeck, 2000). Hybridization may also cause outbreeding depression through disrupting co-adapted gene complexes in established species and may lead to negative selection pressure in some cases (Arnold and Hodge, 1995; Darwin, 1883).

A number of Prunus species are the result of natural hybridization and polyploidy (see the examples in Knight, 1969). In some Prunus species, hybridization has caused the production of progeny which are more tolerant to certain ecological conditions as is the case for the plum $\times$ apricot cross. Many ornamental cherries with showy flowers and sour cherry are also the result of hybridization (Kuitert, 1999). Different Prunus species in subgenera Lithocerasus (Microcerasus) have the ability to hybridize with species in the Prunophora (plums and apricot) and Amygdalus (peach and almond) subgenera to produce fertile progeny (Rehder, 1947; Watkins, 1976). Hybridization can be facilitated by long distance outcrossing and all commercial Prunus species are insect pollinated (Delaplane and Mayer, 2000; Jackson, 1986). In fact, outcrossing ability, cultural history, polyploidization, hybridization and introgression have turned the Prunus species into a complex and even ploidy differences among Prunus species do not provide an effective natural biocontainment mechanism.

\section{Cytotaxonomic background of Prunus species}

The genus Prunus belongs to the sub-family Prunoideae of the Rosaceae family with a basic chromosome number of $x=8$. It has several sub-genera and sections which each consist of a number of different species (Knight, 1969; Rehder, 1947). Prunophora, Amygdalus and Cerasus are the most important sub-genera of the Prunus genus in relation to commercial fruit production and each of these contains different sections (Tab. 1).

\section{Plums}

The greatest centers of genetic diversity for plums are near the coasts of both the Caspian and Black Seas (Kovalev, 1939; Vavilov, 1951). Various plum species grow in these regions each adapted to different conditions with some species growing as high as $1800 \mathrm{~m}$ above sea level (Kovalev, 1939). North America is also considered a notable center of genetic diversity for plum species (Ramming and Cociu, 1991). The global area of land dedicated to plum cultivation in 2009 was approximately 2.5 million hectares. Total global farm-gate value for plum production and global export trade value are approximately $\$ 14$ billion and $\$ 1$ billion (US dollars), respectively (FAOSTAT, 2010).

Among Prunus species, plums have the most genetic diversity and they appear to be the center of the Prunus stage (Watkins, 1976; Tab. 1). Plums have been divided into Euprunus (Asian and European) and Prunocerasus (American) groups (Hartmann and Neumuller, 2009; Watkins, 1976). In a phylogenetic study of Eurasian plums a close relationship between Cherry plum or Myrobalan (P. cerasifera Ehrh.), European plum $(P$. domestica L.) and Damson (P. insitica L.) has been demonstrated (Reales et al., 2010). Most plums are selfincompatible or partially self-compatible (Keulemans, 1994). Anthers of plum do not burst in closed flower buds and pollination will not happen before flowers open (Szabo, 2003). Interspecific fertilization is common in plums. Pollination with other varieties greatly increases the speed of fertilization and enhances fruit set (Keulemans, 1994). Cherry plum is a good pollinator for Japanese plum (P. salicina Lindley.) and European plum and Japanese plum commonly engage in mutual fertilization, while inter-incompatibility is a rare phenomenon in European plum (Szabo, 2003).

Japanese plum has successfully hybridized (both with and without assistance) with other plum species including P. simonii Carr. and American plum (P. americana Marsh.) (Howard, 1945; Okie and Ramming, 1999). American plum is a winter hardy plum native to North America. Japanese plum has a Chinese origin but the exact origin and wild type of European plum is unknown (Hartmann and Neumuller, 2009; Weinberger, 1975). Crane and Lawrence (1934) suggested that hybridization between Cherry plum and Sloe ( $P$. spinosa L.) resulted a triploid that would have been sterile but by doubling its chromosomes a fertile hexaploid could have 
Table 1. Cytotaxonomic characterization of Prunus species (Knight, 1969; Watkins, 1976).

\begin{tabular}{|c|c|c|c|c|c|}
\hline $\begin{array}{l}\text { Prunophora* } \\
\text { Focke. }\end{array}$ & $\begin{array}{l}\text { Amygdalus (L.) } \\
\text { Focke. }\end{array}$ & Cerasus Pers. & $\begin{array}{l}\text { Lithocerasus*** }^{* *} \\
\text { (Microcerasus } \\
\text { Webb.) }\end{array}$ & $\begin{array}{l}\text { Padus } \\
\text { (Moench.) } \\
\text { Koehne. }\end{array}$ & $\begin{array}{l}\text { Laurocerasus } \\
\text { Koehne. }\end{array}$ \\
\hline $\begin{array}{l}\text { Euprunus* } \\
\text { Koehne.: } \\
\text { P. domestica L. } \\
\text { (European plum, } \\
6 x, \text { SC) } \\
\text { P. insititia } \\
\text { L. (Damson plum, } \\
6 x \text { ) } \\
\text { P. cerasifera } \\
\text { Ehrh. (Cherry plum } \\
\text { or Myrobalan, 2, 3, } \\
4,6 x \text { ) } \\
\text { P. spinosa L. } \\
\text { (Black thorn or } \\
\text { Sloe, 2, 3, 4, 5, 6x, } \\
\text { SC) } \\
\text { P. salicina Lindley. } \\
\text { (Japanese plum, 2, } \\
4 x \text { ) } \\
\text { P. simonii Carr. (?x) }\end{array}$ & $\begin{array}{l}\text { Euamygdalus } \\
\text { Schneid.: } \\
\text { P. persica (L.) } \\
\text { Batsch. (Peach, } \\
\text { 2x, EC) } \\
\text { P. mira Koehne. } \\
\text { (2x) } \\
\text { P. davidiana } \\
\text { (Carr.) Franch. } \\
\text { (2x) } \\
\text { P. ferganensis } \\
\text { Kost. ( } 2 x) \\
\text { P. communis } \\
\text { Archang., } \\
\text { Syn. par Amyg- } \\
\text { dalus communis } \\
\text { L. (Almond, } 2 x \text { ) } \\
\text { P. fenzliana } \\
\text { Fritsch. ( } 2 x) \\
\text { P. scoparia } \\
\text { (Spach) } \\
\text { Schneid. } \\
\text { ( } 2 x \text { ) } \\
\text { P. webbii Spach. } \\
\text { ( } 2 x \text { ) } \\
\text { P. triloba Lindl. } \\
\text { (8x) }\end{array}$ & $\begin{array}{l}\text { Eucerasus } \\
\text { Koehne.: } \\
\text { P. avium L. } \\
\text { (Sweet cherry, } \\
2,3,4 x, \text { PW, } \\
\text { SR) } \\
\text { P. cerasus L. } \\
\text { (Sour cherry, 4, } \\
5 x, \text { PW, SR) } \\
\text { P. fruticosa } \\
\text { Pall. (Ground } \\
\text { cherry, 2, 4x) }\end{array}$ & $\begin{array}{l}\text { P. besseyi } \\
\text { Baliey. }(2 x) \\
\text { P. pumila } \mathrm{L} \text {. } \\
\text { (Sand cherry, } \\
2 x) \\
\text { P. tomentosa } \\
\text { Thunb. } \\
\text { (Manchu } \\
\text { cherry, } 2 x, \text { EC) } \\
\text { P. glandulosa } \\
\text { Thunb. (Flow- } \\
\text { ering almond, } \\
2 x, \text { SC) }\end{array}$ & $\begin{array}{l}\text { P. serotina } \\
\text { Ehrh. (Black } \\
\text { cherry, } 4 x, \\
\text { PW, invasive) } \\
\text { P. virginiana L. } \\
\text { (Chock cherry, } \\
4 x, \text { PW) }\end{array}$ & $\begin{array}{l}\text { P. laurocerasus } \\
\text { L. (Cherry laurel, } \\
8 x \text {, evergreen) }\end{array}$ \\
\hline $\begin{array}{l}\text { Prunocerasus } \\
\text { Koehne.: } \\
\text { P. americana } \\
\text { Marsh. (American } \\
\text { plum, } 2 x, \text { PW) } \\
\text { P. nigra } \\
\text { Ait. (Canada plum, } \\
\text { 2x, PW) } \\
\text { P. angustifolia } \\
\text { Marsh. (Chickasaw } \\
\text { plum, 2x, PW) } \\
\text { P. umbellata Ell. } \\
\text { (Hog plum, } 2 x \text {, } \\
\text { PW) } \\
\text { P. maritima Marsh. } \\
\text { (Beach plum, } 2 x \text { ) }\end{array}$ & & $\begin{array}{l}\text { Mahaleb } \\
\text { Focke: } \\
\text { P. pensylvanica } \\
\text { L. } f \text {. (Pin } \\
\text { cherry, PW, } \\
\text { SR) } \\
\text { P. mahaleb L. } \\
\text { (Mahaleb) } \\
\text { P. emarginata } \\
\text { Dougl. (PW) }\end{array}$ & & & \\
\hline
\end{tabular}


Table 1. Continued.

\begin{tabular}{|l|l|l|l|l|l|}
\hline $\begin{array}{l}\text { Prunophora* } \\
\text { Focke. }\end{array}$ & $\begin{array}{l}\text { Amygdalus (L.) } \\
\text { Focke. }\end{array}$ & $\begin{array}{l}\text { Cerasus Pers. } \\
\text { Armenica (Lam.) }\end{array}$ & $\begin{array}{l}\text { Lithocerasus** } \\
\text { (Microcerasus } \\
\text { Webb.) }\end{array}$ & $\begin{array}{l}\text { Padus } \\
\text { (Moench.) } \\
\text { Koehne. }\end{array}$ & $\begin{array}{l}\text { Laurocerasus } \\
\text { Koehne. }\end{array}$ \\
$\begin{array}{l}\text { P. armenica L. } \\
\text { (Apricot, } 2 x \text { ) }\end{array}$ & & & & \\
$\begin{array}{l}\text { P. mume Sieb. et } \\
\text { Zucc. } \\
\text { (Chinese apricot or }\end{array}$ & & & & & \\
Mei, 2, 3x) & & & & & \\
$P$. sibirica L. & & & & \\
(Siberian apricot, & & & & & \\
$2 x$ ) & & & & \\
\hline
\end{tabular}

$x$ : Basic chromosome number $=8$.

PW: Potential weed, present as a weed in USA with an unknown rank of importance (Holm et al., 1979); SR: spreading to road side in N. America; SC: spreading from cultivation in N. America; EC: escaped from cultivation in N. America (Scoggan, 1978).

* Note 1: Some workers have mentioned both Prunophora and Euprunus as Prunus but here we cite the classification of Knight (1969) and Watkins (1976) for less overlap in names.

**Note 2: Knight (1969) and Watkins (1976) assigned Lithocerasus to Cerasus but a recent molecular analysis revealed that Lithocerasus species are genetically closer to members of subgenera Prunophora (plum and apricot) and Amygdalus (peach and almond) than cherry and it was proposed that Lithocerasus should be assigned to subgenera Prunophora and Amygdalus (Shimada et al., 2001). Since phenotypically, Lithocerasus species are similar to Cerasus and genetically similar to Prunophora and Amygdalus the best classification would be the Ingram (1948) classification as he considered Lithocerasus a separate subgenus of Prunus.

been formed similar to European plum. The size, flavor, color and shape of the fruits in European plum support the above origin hypothesis (Weinberger, 1975). Others have proposed that European plum evolved from Cherry plum (Zohary, 1992).

Cultivated plums can readily hybridize with wild plum species (Watkins, 1976). They also hybridize with apricot (Knight, 1969; Weinberger, 1975), cherry (Knight, 1969; Rullo, 2009; Weinberger, 1975) and peach or nectarine (Ramming, 2004). For example, Rullo (2009) found that from only one limb of Japanese plum hand pollinated using sweet cherry pollen two hundred seeds were collected from which five viable seedlings were produced. Crosses between Cherry plum (from the Euprunus section in Subg. Prunophora) and P. pumila L. (from subg. Lithocerasus) have been shown to result in a fertile hybrid called P. $\times$ cistena N. E. Hansen. (Knight, 1969; Ramming and Cociu, 1991).

All interspecific crosses between plum species (P. domestica, P. salicina, $P$. cerasifera) or their hybrids (P. salicina $\times$ P. cerasifera) and apricots (as pollen parent) are known as Plumcot (reviewed in Blažek, 2007). Some plumcots have attractive pink double flowers and red leaves and are produced as ornamentals in Asia (Okie, 2005). Plumcots are tolerant to many plum diseases including bacterial spot disease, bacterial canker disease and plum leaf scaled. Plumcots resemble apricots more than plums (Okie, 2005) and most plum $\times$ apricot hybrids are self-infertile (Ramming, 2004).

Successful gene flow requires flowering synchrony among compatible individuals. It has been reported that European plum blooms one week later than Cherry plum and Japanese plum (Szabo, 2003). The start of blooming time and the length of blooming phase are inherited but they are largely modified by environmental conditions including temperature and sunshine. Differences in the start of blooming are more obvious when the weather before blooming is rainy and cool. Also plums that start blooming late will have a shorter blooming period whereas the blooming period in earlier blooming plants is longer (Szabo, 2003).

The first GM Prunus species that has been deregulated in US is a virus resistant plum (European plum, $P$. domestica) and, according to published reports, this GM virus resistance trait is easily transferred to progeny via pollen mediated gene flow and hybrids produced from GM plum parents have been shown to be effectively PPVresistant (Scorza et al., 1998, 2007). Assisted crosses of GM plum (as a pollen donor) with commercial plum cultivars have been shown to produce fertile progeny that 
express the virus resistance (Ravelonandro et al., 2002). In their study, Ravelonandra et al. (2002) showed that the virus resistance trait was transferred in a near-Mendelian fashion. Successful trangene flow from GM to non-GM plum trees has been recorded at a distance of $520 \mathrm{~m}$ at a rate of 2 out of 2950 seeds (APHIS Petition 04-26401p). Although this gene flow level is low $(0.067 \%)$ it is a level sufficient to cause market issues in jurisdictions where given events have not yet been deregulated. There are no published reports or studies on the potential for pollen mediated transgene flow from GM plum to other compatible Prunus species but the inter-compatibility of European plum and other Prunus species has long been documented (Knight, 1969; Szabo, 2003).

\section{Apricot}

Western Asia and China are the centers of genetic diversity for apricot (Vavilov, 1951). Four major ecogeographical groups of apricot (Central Asia, IranoCaucasian, European, and Chinese) have been distinguished by Kostina (1969 cited in Mehlenbacher et al., 1991). Most cultivated apricots are $P$. armeniaca L. The global area of commercial apricot cultivation in 2009 was approximately 0.5 million hectares. Total global farmgate value for apricot production in 2009 was estimated to be $\$ 3.4$ billion (US dollars) and global export trade value was estimated at $\$ 0.54$ billion (US dollars) (FAOSTAT, 2010).

Apricot is an early blooming species with flowering onset from the end of February to early April depending on variety and climate (Szabo et al., 2003a). In regions with mild climates differences in flowering onset among varieties can be great. Both self-incompatiblity and compatibility have been reported for apricot (Knight, 1969). The majority of European varieties are selffertile but most Asian and Caucasian varieties are selfincompatible. Open pollination, even in highly self-fertile varieties results in greater fruit set than self-pollination (Szabo et al., 2003a). Interspecific apricot hybrids, various plum $\times$ apricot, sand cherry $\times$ apricot, peach $\times$ apricot and almond $\times$ apricot hybrids are all possible (reviewed in Mehlenbacher et al., 1991). The fertility of apricot $\times$ almond or apricot $\times$ peach hybrids is low. Successful hybridization of hexaploid plum $(P$. domestica, European plum) with apricot results in fertile tetraploid progeny (Mehlenbacher et al., 1991). Prunus $\times$ dasycarpa Ehrh. is a typical example of natural hybridization of Cherry plum and apricot (Mehlenbacher et al., 1991). This hybrid is smaller than apricot but it is highly resistant to many fungal diseases and it has showy flowers. This hybrid can backcross with its parents but fruit set is higher when plum is the pollen donor. P. besseyi
Bailey. a species from subg. Lithocerasus can successfully hybridize with apricot and produce a hybrid with many desirable traits including disease resistance, reduced tree size and adaptation to severe ecological conditions (Mehlenbacher et al., 1991). Actually P. besseyi can be crossed with many Prunus species and it has been suggested as bridge for transferring genes among Prunus species (Mehlenbacher et al., 1991). P. maritima Marsh. a native plum of North America (found along a region stretching from Virginia to Nova Scotia) can also easily hybridize with apricot and offers genes for adaptation to ecological conditions (reviewed in Mehlenbacher et al., 1991).

P. mume Sieb. et Zucc., an ornamental and fruiting tree, a close relative of apricot, can also hybridize with other Prunus species, including apricot, Japanese plum and Cherry plum, to produce fully or semi fertile progeny (Knight, 1969). There is a question about the genetic relationship between $P$. mume and apricot. Some researchers have shown that $P$. mume is a closer relative of European plum than apricot (Lee and Wen, 2001).

\section{Peach}

Peach (P. persica (L.) Batsch.) is native to China (Vavilov, 1951). The global area of peach cultivation in 2009 was approximately 1.33 million hectares. Total global farmgate value for peach production in 2009 was estimated to be $\$ 11$ billion (US dollars) and global export trade value was estimated at $\$ 1.7$ billion (US dollars) (FAOSTAT, 2010).

Depending on the variety and the region, flowering onset for peach ranges from February to April. Bud dormancy and rate of spring warming can affect the time of flowering onset. The length of the lowering period is also affected by temperature. Late short springs produce short flowering periods while early long springs produce long flowering periods (Szabo et al., 2003b). Flowering periods can last 14 to 21 days but when temperatures are high can be as short as 5 to 9 days (Nyeki and Szabo, 1996). Peach varieties are categorized as highly selffertile (above $50 \%$ fruit set), intermediately self-fertile (20 to $50 \%$ fruit set) and rarely self- fertile (below $20 \%$ fruit set) (Bellini et al., 1984). In a study, the mean selffertility of 120 varieties over 13 years varied between 1.5 and $54 \%$ with an individual maximum of $89.9 \%$ (Nyeki et al., 1998). For peach, the rate of fruit set for open pollinated flowers is higher than for self-pollinated flowers. Cross-incompatibility has not been reported in peach and there is good evidence that allogamy produces higher rates of fruit set than self-pollination (Szabo et al., $2003 b$ ). Self-fertile varieties favour allogamy when the distance between varieties is less than $40 \mathrm{~m}$ (Szabo et al., 
2003b). This suggests the minimum distance for interindividual gene flow in peach and highlights the possibility of high levels of accidental gene flow. Many almond, plum, cherry and apricot species are pollen compatible with peach but the progeny of peach $\times$ almond hybrids are the most fruitful (Knight, 1969). Peach is closely related to almond and other members of the subg. Amygdalus which means that many wild almond species can hybridize with peach and produce fertile progeny (Hesse, 1975; Knight, 1969; Scorza and Okie, 1991). The species most closely related to peach are $P$. davidiana (Carr.) Franch, $P$. kansuensis Rehd. and P. mira Koehne. Except for $P$. mira, these are all sexually compatible with peach and crossing produces completely viable and fertile hybrids (Martínez-Gómez et al., 2003). Nectarine (P. persica var. nectarine) is a natural mutant of peach that can readily hybridize with peach cultivars. An extensive list and description of cultivars is presented by Frecon $(2004,2006)$ which are the results of crosses between peach and peach or peach and nectarine. All the progenies of these crosses are self-fertile. Although there is good information on the ability of peach to hybridize with a variety of Prunus species there is very limited information on the level of fertility in the F1 hybrids.

\section{Almond}

Natural populations of wild almond are widely distributed in a variety of ecological niches from central Asia to the Mediterranean (Kester et al., 1991). The global area dedicated to almond (P. communis Archang., Syn. Amygdalus communis L.) cultivation in 2009 was approximately 1.76 million hectares. Global farm-gate value and export trade value for almond was $\$ 8.4$ billion and \$2.6 billion (US dollars), respectively (FAOSTAT, 2010).

Almond is one of the earliest flowering fruit trees. Almond and peach are unique in terms of genetic compatibility in that although they have very different phenotypes there is a high level of synteny between their genomes (Arus et al., 2009). It has been hypothesized that this phenomenon is the result of divergent evolutionary paths, each path driven by very different environments (Martínez-Gómez et al., 2003).

It has been proposed that cultivated almonds are derived from P. fenzliana Fritsch. or natural hybridizations of $P$. fenzliana with a range of related species such as P. triloba Lindl. or P. webbii Spach. (Arus et al., 2009; Socias i Company, 2002). Cultivated and wild relatives of almond and peach (Tab. 1) readily hybridize and the progeny are highly fertile (Gradziel, 2003; Watkins, 1976). With a few exceptions, almonds are typically selfincompatible and honeybees play an important role in pollination (Socias i Company, 1990). In addition, selffertile almond varieties produce higher yields under allogamous pollination conditions and fruit set increases when the branches of pollen donors are in the crown rather than near the base of the tree (Soltesz et al., 2003).

\section{Cherries}

The global area of cherry in 2009 was approximately 0.3 million hectares. Total global farm-gate value was approximately $\$ 4.7$ billion (US dollars) and global export trade value was approximately $\$ 0.8$ billion (US dollars) (FAOSTAT, 2010).

Cherries originated in central Asia, close to the Caspian and Black Seas (Vavilov, 1951; Watkins, 1976). They spread slowly from that region mostly via birds (Jackson, 1986). Sour cherry (P. cerasus L., $4 x$ ) is believed to be the product of natural interspecific hybridization between sweet cherry ( $P$. avium L., $2 x)$ and ground cherry (P. fruticosa Pall., 4x) (Olden and Nybom, 1968). Ground cherry is the most winter hardy cherry species. It grows wild in Southeast Asia and Western Europe and can survive temperatures of -45 to $-50{ }^{\circ} \mathrm{C}$ (Iezzoni et al., 1990). Another example of a successful cherry hybrid is Duke cherry $(P . \times$ gondouinii Rehd.), a fertile tetraploid that is the result of pollination of sour cherry by unreduced gametes of sweet cherry (Faust and Suranyi, 1997).

Sweet cherries are mostly self-incompatible and generally flower earlier than sour cherries, but their flowering periods can overlap (Nyeki et al., 2003a). "Stella" (Lapins, 1970) is a self-compatible sweet cherry that has been widely used as a progenitor in self-compatible sweet cherry breeding. Self-compatibility has been induced in sweet cherry by irradiation (Lewis, 1949). Depending on variety and regional climate, sweet cherry flowers from April to May and the flowering period can range from 5 to 26 days (Nyeki et al., 2003a). Among stone fruits, sour cherries flower late. They are mostly self-compatible but still set more fruit if they are cross pollinated (with other varieties or close relatives). The rate of autogamous fruit set changes yearly in sour cherry. A given sour cherry variety may be self-fertile in one year and self-infertile in another year. Sweet cherry and sour cherry can fertilize each other (Nyeki et al., 2003b). In a study designed to assess the effect of distance from the pollen source on yield, Nyeki and Soltesz (1977) found that when separation distances were greater than $58 \mathrm{~m}$ the self-infertile cherries did not bear fruit.

Cherries have been successfully hybridized (mostly via assistance) with plum, apricot and peach to aid in the development of more robust cherry germplasm (Fogle, 1975). North American cherry species in the subg. Lithocerasus (such as $P$. besseyi) are derived from 
the central Asian Prunus species and they can therefore form a genetic bridge for hybridization between the Creasus, Amygdalus and Prunophora subgenera (Iezzoni et al., 1990; Watkins, 1976). Species in the subg. Lithocerasus show a greater morphological resemblance to cherries but their genome is closer to Amygdalus and Prunophora (Shimada et al., 2001).

\section{WEEDY AND INVASIVE PRUNUS SPECIES: THE EXAMPLE OF BLACK CHERRY}

Transgene movement via pollen and/or seed occurs within a complex of sub-populations which exist across agricultural and semi-natural landscapes. These subpopulations include crops, volunteers, weeds and feral (or invasive) stands (Bagavathiannan and Van Acker, 2008). Without very strict containment practices, transgenes can move among these sub-populations which taken together comprise a metapopulation with respect to a given transgene (Knispel et al., 2008). In this context, responsible transgene containment efforts for either biosafety or coexistence purposes must take into account all possible sub-populations and possible pollen and/or seed movement opportunities (and routes) between them.

Less than half a century ago some Prunus tree species were classified as weeds in the US (Holm et al., 1979). These were mostly plum and cherry species (Tab. 1). Today one of those weeds (black cherry; P. serotina Ehrh., $4 x$ ) is considered an invasive weed in Europe. Black cherry is from the subgenus Padus and is native to North America. It is an important quality timber source but it is invading the forests of Europe. It was introduced to Europe in the seventeenth century as a desirable ornamental plant, valuable timber tree and soil improver. During the first half of the twentieth century it was extensively planted in Western Europe in the understory of pine plantations for fire protection and soil improvement purposes. Recently, conservationists and scientists have noticed and documented its detrimental effects on diversity in the herb layer and on the regeneration of native trees (Starfinger et al., 2003). Black cherry is semi-shade tolerant and produces 1500-6000 fruits per tree (Pairon et al., 2006). Its seeds can remain viable for up to three years and it is readily spread long distances by birds and mammals (Wendel, 1972). Black cherry seedlings grow fast and the regeneration cycle from seed to seed is only four years (Pairon et al., 2006). Black cherry is a humanfacilitated invasive Prunus and in light of the existence of an extensive genetically compatible Prunus species complex it is an example that is relevant to biosafety considerations for GM Prunus species. The Prunus species listed as possible weeds by Holm et al. (1979) is not complete, given that the list is only US based and we know that the centres of origin for most Prunus species are Asia minor (around the Caspian and Black seas) and China.

\section{CONCLUDING REMARKS}

The many characteristics of Prunus species highlighted in this review including; genetic diversity, genetic bridging capacity, inter- and intra-specific genetic compatibility, self sterility (in most species), high frequency of open pollination, insect assisted pollination, perennial nature, complex phenotypic architecture (canopy height, heterogeneous crown, number of flowers produced in an individual plant), tendency to escape from cultivation (Scoggan, 1978), and the existence of ornamental and road side Prunus species suggest that there is a substantial potential for pollen mediated gene movement among Prunus species. And unique among commercialized (or potentially commercialized GM crops), gene flow from GM Prunus to non-GM Prunus would be facilitated by functional gene flow both within metapopulations and among species within a species complex. Risk assessments for the release of GM Prunus should consider the role of feral, ornamental and wild species populations in transgene movement as well as the unique Prunus species complex which creates tremendous challenges for transgene containment. The results from this review suggest that the coexistence of GM and non-GM Prunus would be challenging if threshold levels are very low. In addition, the existence of genetically compatible weedy and invasive species within the complex raises environmental biosafety questions which were not broached in the US deregulation process for the plum pox virus resistant GM plum remembering that feral, invasive and weedy populations can act as stepping stones for transgene movement (Bagavathiannan and Van Acker, 2008). For example, within the subg. Cerasus a large number of natural successful crosses and back crosses occur (Rehder, 1947). Lithocerasus species (that have a high level of diversity in North America) could act as a gene flow bridge among different Prunus species (especially Prunophora and Amygdalus species) and produce fertile progeny despite differences in ploidy levels (Iezzoni et al., 1990; Watkins, 1976).

In regard to gene flow within and among Prunus species in the context of risk assessment, this review highlights several areas where greater understanding is required. There remain very few studies, generally, on gene flow within and among Prunus species leaving little data for prediction and assessment. In particular, there is a need to understand the ecology of the Lithocerasus subgenus since it forms a genetic bridge between Eucerasus, Prunophora (plum and apricot) and Amygdalus (peach and almond) subgenera. In addition, there is a complete gap in our understanding of the active genetic relationship 
between escaped and wild Prunus species in their centers of origin. In order to provide information for metapopulation genetic dynamics, gene flow and hybridization studies need to include an examination of the fitness consequences of inter-specific crosses at different hierarchical levels, including ecological, population and landscape.

Received September 12, 2010; accepted November 23, 2010.

\section{REFERENCES}

Arnold ML, Hodge SA (1995) Are natural hybrids fit or unfit relative to their parents? Trends Ecol. Evol. 10: 67-71

Arus P, Gradziel T, Margarida-Oliveira M, Tao R (2009) Genomics of Almond. In Folta KM, Gardiner SE, eds, Genetics and Genomics of Rosaceae, Crops and Models, 6: 187-219, Springer Science

Atanassov D (1932) Plum pox. A new virus disease. Ann. Univ. Sofia, Fac. Agric. Silvic. 11: 49-69

Bagavathiannan MV, Van Acker RC (2008) Crop ferality: implications for novel trait confinement. Agric. Ecosyst. Environ. 127: 1-6

Bagavathiannan MV, Spok A, Van Acker RC (2010) Commercialization of perennial GE crops: looming challenges for Regulatory Frameworks. J. Agric. Environ. Ethics 23: $10.1007 / \mathrm{s} 10806-010-9257-3$

Bellini E, Watkins R, Pomarici E (1984) Descriptor List for Peach (Prunus persica). IBPGR, Rome and CEC, Brussels

Blažek J (2007) A survey of the genetic resources used in plum breeding. Acta Hort. (ISHS) 734: 31-45

Crane MB, Lawrence WJC (1934) The Genetic of Garden Plants. Mac Millan, London

Culley TM, Weller SG, Sakai AK (2002) The evolution of wind pollination in angiosperms. Trends Ecol. Evol. 17: 361369

Darwin C (1883) The Variation of Animals and Plants under Domestication. D. Appleton and Co, New York

de Vries J, Meier P, Wackernagel W (2004) Microbial horizontal gene transfer and the DNA release from transgenic crop plants. Plant Soil 266: 91-104

Delaplane KS, Mayer DF (2000) Crop Pollination by Bees. University Press Cambridge, Cambridge

Dickson EE, Kresovich S, Weeden NF (1991) Isozymes in North American Malus (Rosaceae): Hybridization and species differentiation. Syst. Bot. 16: 363-375

Ellstrand NC, Schierenbeck KA (2000) Hybridization as a stimulus for the evolution of invasiveness in plants? Proc. Natl. Acad. Sci. USA 97: 7043-7050

FAOSTAT (2010) http://faostat.fao.org/. Retrieved 10 October 2010
Faust M, Suranyi D (1997) Origin and dissemination of cherry. Hort. Rev. 19: 263-317

Ferreira SA, Pitz KY, Manshardt R, Zee F, Fitch M, Gonsalves D (2002) Virus coat protein transgenic papaya provides practical control of papaya ringspot virus in Hawaii. Plant Disease 86: 101-105

Fogle HW (1975) Cherries. In Janick J, Moore JN, eds, Advances in Fruit Breeding, Purdue University Press, Indiana, pp 348-336

Frecon JL (2004) Fruit register list 42: Peach. Hort. Sci 39: 1512-1513

Frecon JL (2006) Fruit register list 43: Peach. Hort. Sci 41: 1116-1119

Goodwillie C, Kalisz S, Eckert CG (2005) The evolutionary enigma of mixed mating systems in plants: occurrence, theoretical explanations, and empirical evidence. Ann. Rev. Ecol. Evol. Syst. 36: 47-79

Gradziel TM (2003) Interspecific hybridizations and subsequent gene introgression within Prunus subgenus Amygdalus. Acta Hort. 622: 249-255

Hartmann W, Neumuller N (2009) Plum Breeding. In Jain M, Priyadarshan PM, eds, Breeding Plantation Tree Crops, Temperate Species, Springer Science, Publ., New York, pp 161-231

Hesse CO (1975) Peaches. In Janick J, Moore JN, eds, Advances in Fruit Breeding, Purdue University Press, Indiana, pp 285-331

Ho MW, Cummins J, Saunders P (2007) GM food nightmare unfolding in the regulatory sham. Microb. Ecol. Health. Dis. 19: $66-77$

Holm L, Pancho J, Herberger J, Plucknett D (1979) A Geographical Atlas of World Weeds. John Wiley and Sons, New York

Howard WL (1945) Luther Burbank's plant contributions. Calif. Agr. Expt. Sta. Bul. 691

Iezzoni AF, Schmidt H, Albertini A (1990) Cherries (Prunus). In Moore JN, Ballington JR, eds, Genetic Resources of Temperate Fruit and Nut Crops (ISHS), The Netherlands, pp 111-173

Ingram C (1948) Ornamental Cherries. Country Life Limited, London

Jackson DI (1986) Temperate and Subtropical Fruit Production. Butterworth of New Zealand, p 249

Kester DE, Gradziel TM, Grasselly C (1991) Almonds (Prunus). In Moore JN, Ballington HJ, eds, Genetic Resources of Temperate Fruit and Nut Crops (ISHS), The Netherlands, pp 701-758

Keulemans J (1994) Pollination and fruit set in self incompatible plum cultivars. Acta Hort. 359: 260-268

Knight RL (1969) Abstract Bibliography of Fruit Breeding and Genetics to 1965; Prunus. Commonwealth Bureau of Horticulture and Plantation Crops, p 649

Knispel AL, McLachlan SM, Van Acker RC, Friesen LF (2008) Genetically engineered multiple herbicide resistance in escaped canola populations. Weed Sci. 56: 72-80 
Kovalev NV (1939) Ecological differentiation of the cherry plum Prunus cerasifera Ehrh. (s.1.Kov.). Dokl. Akad. Nauk. SSR. New Ser. 23: 285-288

Kron P, Husband BC (2009) Hybridization and the reproductive pathways mediating gene flow between native Malus coronaria and domestic apple, M-domestica. Botany 87: 864874

Kuitert W (1999) Japanese Flowering Cherries. Timber Press, Portland, Oregon

Lapins KO (1970) The Stella cherry. Fruit Varieties Hort. Digest. 24: 19-20

Latham JR, Wilson AK (2008) Transcomplementation and synergism in plants: implications for viral transgenes? Mol. Plant Pathol. 9: 85-103

Lee S, Wen J (2001) A phylogenetic analysis of Prunus and the Amygdaloideae (Rosaceae) using ITS sequences of nuclear ribosomal DNA. Am. J. Bot. 88: 150-160

Lewis D (1949) Structure of the incompatibility gene. II. Induced mutation rate. Heredity 3: 339-355

Martínez-Gómez P, Arulskar S, Potter D, Gradziel, TM (2003) Relationships among peach, almond, and related species as detected by simple sequence repeat markers. J. Am. Soc. Hort. Sci. 128: 667-671

Marvier M, Van Acker RC (2005) Can crop transgenes be kept on a leash? Front. Ecol. Environ. 3: 99-106

Mehlenbacher SA, Cociu V, Hough F (1991) Apricots (Prunus). In Moore JN, Ballington HJ, eds, Genetic Resources of Temperate Fruit and Nut Crops, International Society for Horticultural Science, The Netherlands, pp 65107

Miki B, McHugh S (2004) Selectable marker genes in transgenic plants: applications, alternatives and biosafety. $J$. Biotechnol. 107: 193-232

Nyeki J, Soltesz M (1977) Effect of the distance and proportion of the pollen donor variety on fruit setting and fruit yield Pandy sour cherry. Acta Agr. Sci. Hung. 26: 87-89

Nyeki J, Szabo Z (1996) Flowering phenology of peach cultivars under Hungarian ecological conditions. Acta Hort. 374: 181-184

Nyeki J, Szabo Z, Andrasfalvy A, Soltesz M, Szel I (1998) Open pollination and autogamy of peach and nectarine varieties. Acta Hort. 465: 279-284

Nyeki J, Szabo Z, Soltesz M (2003a) Sweet cherry (Prunus avium L.). In Kozma P, Nyeki J, Soltesz M, Szabo Z, eds, Floral biology, pollination and fertilization in temperate zone fruit species and grape, Akademiai Kiado, Budapest, pp 341358

Nyeki J, Szabo Z, Soltesz M (2003b) Sour cherry (Prunus cerasus L.). In Kozma P, Nyeki J, Soltesz M, Szabo Z, eds, Floral biology, pollination and fertilization in temperate zone fruit species and grape, Akademiai Kiado, Budapest, pp 359382

Okie WR (2005) 'Spring Satin' plumcot. J. Am. Pomological Soc. 59: 119-124

Okie WR, Ramming TW (1999) Plum breeding worldwide. Hort. Tech 9: 162-176
Olden EJ, Nybom N (1968) On the origin of Prunus cerasus L. Hereditas 59: 327-345

Pairon M, Chabrerie O, Mainer Casado C, Jacquemart A-L (2006a) Sexual regeneration traits linked to black cherry (Prunus serotina Ehrh.) invasiveness. Acta Oecol. 30: 238247

Pairon M, Jonard M, Jacquemart A-L (2006b) Modeling seed dispersal of black cherry, an invasive forest tree: how microsatellites may help? Can. J. For. Res. 36: 1385-1394

Pascal T, Kervella J, Pfeiffer F, Sauge MH, Esmenjaud D (1998) Evaluation of the interspecific progeny Prunus. persica $\mathrm{cv}$. Summergrand $\times$ Prunus. davidiana for disease resistance and some agronomic features. Acta Hort. 465: 185192

Patterson B, Vaillancourt RE, Pilbeam DJ, Potts BM (2004) Factors affecting variation in outcrossing rate in Eucalyptus globulus. Aust. J. Bot. 52: 773-780

Petit RJ, Hampe A (2006) Some evolutionary consequences of being a tree. Ann. Rev. Ecol. Evol. Syst. 37: 187-214

Ramming DW (2004) Fruit Register list 43: Plum and Plum hybrids. USDA-ARS Crop Diseases, Pests and Genetics, San Joaquin Valley Agricultural Sciences Center, Parlier

Ramming DW, Cociu V (1991) Plums (Prunus). Acta Hort. 290: $235-290$

Ravelonandro M, Briard P, Monsion M, Scorza R, Renaud $\mathbf{R}$ (2002) Stable transfer of the plum pox virus (PPV) capsid transgene to seedlings of two French cultivars 'Prunier d'Ente 303' and 'Quetsche 2906', and preliminary results of PPV challenge assays. Acta Hort. 577: 91-96

Reales A, Sargent DJ, Tobutt KR, Rivera D (2010) Phylogenetics of Eurasian plums, Prunus L. section Prunus (Rosaceae), according to coding and non-coding chloroplast DNA sequences. Tree Gen. Genomes 6: $37-45$

Rehder A (1947) Manual of Cultivated Trees and Shrubs, 2nd edn, Macmillan company, New York

Reim S, Flachowsky H, Michael M, Hanke MV (2006) Assessing gene flow in apple using a descendant of Malus sieversii var. sieversii f. niedzwetzkyana as an identifier for pollen dispersal. Environ. Biosafety Res. 5: 89-104

Rubio M, Martínez-Gómez P, Dicenta F (2003) Resistance of almond cultivars to Plum pox virus (sharka). Plant Breed. 122: $462-464$

Rhymer JM, Simberloff D (1996) Extinction by hybridization and introgression. Ann. Rev. Ecol. Sys. 27: 83-109

Rullo J (2009) Plum $\times$ cherry interspecific hybrid tree named Nadia. USA Plant Patent Application NO. US2009/0044301 P1

Scoggan HJ (1978) The Flora of Canada, Part 3. National Museum of Natural Sciences, Canada

Scorza R, Okie WR (1991) Peaches (Prunus). Acta Hort. 290: 177-231

Scorza R, Ravelonandro M, Callahan AM, Cordts JM, Fuchs M, Dunez J, Gonsalves D (1994) Transgenic plums 
(Prunus domestica L.) express the plum pox virus coat protein gene. Plant. Cell Rpt. 14: 18-22

Scorza R, Callahan AM, Levy L, Damsteegt V, Ravelonandro M (1998) Transferring potyvirus coat protein genes through hybridization of transgenic plants to produce plum pox virus resistant plums (Prunus domestica L.). Acta Hort. 472: 421-427

Scorza R, Callahan A, Levy L, Damsteegt V, Webb K, Ravelonandro M (2001) Post-transcriptional gene silencing in plum pox virus resistant transgenic European plum containing the plum pox potyvirus coat protein gene. Transgenic Res. 10: 201-209

Scorza R, Hily JM, Callahan AM, Malinowski T, Cambra M, Capote N, Zagrai I, Damsteegt V, Briard P, Ravelonandro M (2007) Deregulation of Plum Pox resistant transgenic plum 'HoneySweet'. In Litz RE, Scorza R, eds, Proceedings of the international symposium on biotechnology of temperate fruit crops and tropical species. Acta Hort. 738: 669-673

Shimada T, Hayama H, Nishimura K, Yamaguchi M, Yoshida M (2001) The genetic diversities of 4 species of subg. Lithocerasus (Prunus, Rosaceae) revealed by RAPD analysis. Euphytica 117: 85-90

Singh Z, Sansavini S (1998) Genetic transformation and fruit crop improvement. In Janick J, ed, Plant Breeding Reviews (Vol. 16), John Wiley and Sons, pp 87-134

Socias i Company R (1990) Breeding self-compatible almonds. Plant Breed. Rev. 8: 313-338

Socias i Company R (2002) The relationship of Prunus webbii and almond revisited. Nucis-Newsletter 11: 17-19

Soltesz M, Nyeki J, Szabo Z (2003) Almond (Amygdalus communis L.). In Kozma P, Nyeki J, Soltesz M, Szabo Z, eds, Floral biology, pollination and fertilization in temperate zone fruit species and grape, Akademiai Kiado, Budapest, pp 435449
Starfinger U, Kowarik I, Rode M, Schepker H (2003) From desirable ornamental plant to pest to accepted addition to the flora? - The perception of an alien tree species through the centuries. Biol. Inv. 5: 323-335

Szabo S (2003) Plum (Prunus domestica L). In Kozma P, Nyeki J, Soltesz M, Szabo Z, eds, Floral biology, pollination and fertilization in temperate zone fruit species and grape, Akademiai Kiado, Budapest, pp 383-410

Szabo S, Nyeki J, Soltesz M (2003a) Apricot (Prunus armeniaca L.). In Kozma P, Nyeki J, Soltesz M, Szabo Z, eds, Floral biology, pollination and fertilization in temperate zone fruit species and grape, Akademiai Kiado, Budapest, pp 411-423

Szabo S, Nyeki J, Soltesz M (2003b) Peaches (Prunus persica L.). In Kozma P, Nyeki J, Soltesz M, Szabo Z, eds, Floral biology, pollination and fertilization in temperate zone fruit species and grape, Akademiai Kiado, Budapest, pp 425-434

Van Acker RC, McLean N, Martin RC (2007) Development of quality assurance protocols to prevent GM-contamination of organic crops. In Cooper U, Niggli J, Leifert C, eds, Handbook of Organic Food Safety and Quality, CRC Press, Boca Raton, pp 466-489

Vavilov NI (1951) The Origin, Variation, Immunity and Breeding of Cultivated Plants. Chronica botanica, v. 13, New York, Ronald Press, p 364

Watkins R (1976) Cherry, Plum, Peach, Apricot and Almond in Evolution of crop plants. In Simmonds NW, ed, Longman, New York, pp 242-247

Weinberger JH (1975) Plums. In Janick J, Moore JN, eds, Advances in Fruit Breeding, Purdue, University Press, West Lafayette, pp 336-347

Wendel GW (1972) Longevity of black cherry seed in the forest floor. USDA Forest Service, Research Note NE-149, Northeastern Forest Experiment Station, Upper Darby

Zohary D (1992) Is the European plum, Prunus domestica L., a $P$. cerasifera Ehrh. $\times$ P. spinosa L. allo-polyploid? Euphytica 60: $75-77$ 